\title{
Multiple functions of hypoxia-regulated miR-210 in cancer
}

Qin Qin ${ }^{1,2}$, Wei Furong ${ }^{3}$ and Li Baosheng ${ }^{1,2^{*}}$

\begin{abstract}
MicroRNAs (miRNAs) are small noncoding RNAs that regulate gene expression post-transcriptionally. miRNAs can be induced by a variety of stresses such as hypoxia, and are involved in diverse biological processes including differentiation, cell proliferation, cell death, and tumorigenesis. Hypoxia, a common feature of tumor microenvironment, can induce a number of miRNAs expression. miRNA-210 (miR-210) is one of the hypoxia-regulated-miRNAs, which has been investigated extensively in cancer. However, paradoxically opposing results were documented regarding whether it is an oncogene or a tumor suppressor, and whether it is a positive or negative prognostic biomarker. In the present review, we focus on the following investigations of miR-210: 1) its functions of as an oncogene, 2) its functions as a tumor suppressor, 3) its functions in mitochondrial metabolism, and finally, the diagnostic and prognostic value of miR-210 in cancer researches.
\end{abstract}

Keywords: microRNA, Hypoxia, miR-210, Proliferation, Apoptosis, Angiogenesis, Metabolism, Diagnosis, Prognosis

\section{Introduction}

MicroRNAs (miRNAs) are small noncoding RNAs that regulate gene expression post-transcriptionally by pairing to 3' untranslated regions (UTRs), coding sequences or 5' UTRs of target messenger RNAs (mRNAs), which in most cases leads to translation inhibition or mRNA degradation [1]. In mammals, miRNAs are predicted to regulate the activity of approximately $50 \%$ of all protein-coding genes [2]. Due to the widespread regulating functions, miRNAs are involved in almost every cellular process including differentiation, cell proliferation, cell death, and tumorigenesis [3].

Hypoxia is a common feature of the tumor microenvironment [4] and has been an extensively investigated field in cancer researches demonstrating its critical role in various physiologic and pathologic processes including cell proliferation, cell survival, angiogenesis, metabolism, tumor invasion and metastasis [5]. It is widely accepted that hypoxia represents an independent adverse prognostic factor in many tumor types $[4,6]$.

\footnotetext{
* Correspondence: Baoshli@yahoo.com

'Department of Radiation Oncology, Shandong Cancer Hospital, Shandong University, Jiyan Road 440, Jinan 250117, P.R. China

${ }^{2}$ Department of Radiation Oncology, Shandong Cancer Hospital, Shandong Academy of Medical Sciences, Jinan 250117, P.R. China

Full list of author information is available at the end of the article
}

Since the first article demonstrated the functional link between hypoxia and miRNAs expression, which identified a specific hypoxia-regulated miRNAs (HRMs) playing an important role in cell survival in low oxygen environment [7], that more and more HRMs were identified [8-12]. Although discrepancies exist among HRMs identified by different research groups, the up-regulation of miR-210 induced by hypoxia has been consistent in all published studies in both normal and transformed cells, which implies an essential role of miR-210 for cell adaptation to hypoxia [13-15]. Not only in vitro studies correlated miR-210 with hypoxia, in vivo investigation also verified it. In tumor tissues such as breast cancer and head and neck cancers, miR-210 expression levels have been demonstrated to be correlated with hypoxia gene signatures, which suggested a direct connection between miR-210 expression and hypoxia $[16,17]$.

miR-210 is an intronic miRNA located within the genomic loci of transcript AK123483 [18]. While most studies reported miR-210 regulation in a hypoxia-inducible factor-1 (HIF-1)-dependent way [19-21], HIF-2-dependent $[22,23]$ and HIF-independent $[24,25]$ regulation of miR-210 have also been reported. The master HRM miR-210 has been investigated intensively, which has identified a variety of functionally important targets involved in cell cycle 
regulation [18,22,26-30], cell survival [31-36], differentiation [37-40], angiogenesis [41-51] as well as metabolism [52-57].

However, paradoxically opposing results were documented with regard to whether miR-210 is an oncogene or a tumor suppressor, and whether it is a positive or negative prognostic biomarker. In the present review, we focus on the following investigations of miR-210: 1) its functions of as an oncogene, 2) its functions as a tumor suppressor, 3) its functions in mitochondrial metabolism, and finally, the diagnostic and prognostic value of miR-210 in cancer researches.

\section{miR-210 functions as an oncogene}

Since miR-210 is up-regulated ubiquitously and robustly in hypoxic cells and hypoxia is a key feature of solid tumors, it is reasonable to explore the functions of miR-210 in tumorigenesis. With the development of bioinformatic miRNA targets prediction tools as well as the improvement of experimental approaches, many diverse targets of miR-210 have been identified, revealing an important role of miR-210 in tumor initiation and progression [58]. Table 1 presents the identified targets of miR-210, showing the oncogenic role of miR-210.

\section{miR-210 promotes cancer cell proliferation}

Sustaining proliferative capacity is a key hallmark of cancer cells which acquire such capacity through a number of ways: 1) they may produce growth factor ligands themselves and stimulate normal cells in tumor-associated stroma to supply various growth factors, 2) they may harbor activating mutations to sustain proliferative signaling, and 3) they may disrupt negative-feedback loops that attenuate proliferative signaling [59].

Over the past few years, the role of hypoxia-inducible miR-210 in cell cycle regulation has been a subject of considerable interest and has provided reliable evidence supporting a role for miR-210 in promoting cancer cell proliferation [18,21,22,26-30]. Zhang and colleagues [22]

Table 1 Targets of miR-210 functioning as oncogene

\begin{tabular}{|c|c|c|c|}
\hline Symbol & Description & Related function & Involved cell type \\
\hline \multirow[t]{5}{*}{ MNT [22] } & \multirow[t]{5}{*}{ MAX network transcriptional repressor } & \multirow[t]{5}{*}{ Regulate cell proliferation } & HCT116 \\
\hline & & & HeLa \\
\hline & & & HFF-pBABE \\
\hline & & & ME-180 \\
\hline & & & 786-O-pBABE \\
\hline Casp8ap2 [31] & Caspase 8 associated protein 2 & Regulate apoptosis & MSC \\
\hline \multirow[t]{2}{*}{ PTBP3/ROD1 [61] } & \multirow{2}{*}{$\begin{array}{l}\text { Polypyrimidine tract binding protein } \\
\text { 3/Regulator of differentiation } 1\end{array}$} & \multirow[t]{2}{*}{ Regulate apoptosis } & HEK-293 \\
\hline & & & HUVEC \\
\hline E2F3 [32] & E2F transcription factor 3 & $\begin{array}{l}\text { Regulate apoptosis and } \\
\text { cell proliferation }\end{array}$ & HPASMC \\
\hline \multirow[t]{2}{*}{ BNIP3 [36] } & \multirow[t]{2}{*}{ BCL2/adenovirus E1B $19 \mathrm{kDa}$ interacting protein 3} & \multirow[t]{2}{*}{ Induce apoptosis } & NPC \\
\hline & & & PC12 \\
\hline \multirow[t]{3}{*}{ AlFM3 [27] } & \multirow{3}{*}{$\begin{array}{l}\text { Apoptosis inducing factor, mitochondrion } \\
\text { associated, } 3\end{array}$} & \multirow[t]{3}{*}{ Induce apoptosis } & SMMC-7721 \\
\hline & & & HepG2 \\
\hline & & & $\mathrm{HuH7}$ \\
\hline EFNA3 $[41,64]$ & Ephrin-A3 & Regulate angiogenesis & HUVEC \\
\hline \multirow[t]{2}{*}{ VMP1 [42] } & \multirow[t]{2}{*}{ Vacuole membrane protein 1} & \multirow[t]{2}{*}{ Regulate migration and invasion } & SMMC-7721 \\
\hline & & & $\mathrm{HuH}-7$ \\
\hline \multirow[t]{2}{*}{ RAD52 [66] } & \multirow[t]{2}{*}{ RAD52 homolog (S. cerevisiae) } & \multirow[t]{2}{*}{ Involve in DNA repair } & HeLa \\
\hline & & & MCF-7 \\
\hline \multirow[t]{2}{*}{ PTPN1 [68] } & \multirow{2}{*}{$\begin{array}{l}\text { protein tyrosine phosphatase, } \\
\text { non-receptor type } 1\end{array}$} & \multirow[t]{2}{*}{ Regulate immune response } & IGR-Heu \\
\hline & & & NA-8 \\
\hline \multirow[t]{2}{*}{ HOXA1 [68] } & \multirow[t]{2}{*}{ Homeobox A1 } & \multirow[t]{2}{*}{ Regulate immune response } & IGR-Heu \\
\hline & & & NA-8 \\
\hline \multirow[t]{2}{*}{ TP53।11 [68] } & \multirow[t]{2}{*}{ tumor protein p53 inducible protein 11} & \multirow[t]{2}{*}{ Regulate immune response } & IGR-Heu \\
\hline & & & NA-8 \\
\hline
\end{tabular}


identified MNT, a known MYC antagonist, as a miR-210 target. Overexpression of miR-210 can override hypoxiainduced cancer cell cycle arrest and promote cell proliferation by down-regulating MNT directly and activating c-MYC indirectly. Similarly but in a different way, Yang and colleagues [27] demonstrated that downregulation of miR-210 in hypoxic human hepatoma cells induced cell cycle arrest in the G0/G1, resulting in reduced cancer cell proliferation. However, functional targets of miR-210 contributing to such effect require further researches.

\section{miR-210 inhibits apoptosis and protects cancer cell}

Hypoxic cancer cells are notorious for their resistance to radiotherapy and many conventional chemotherapeutic agents, of which the underlying mechanisms remain to be revealed [3]. As the master HRM, the association of miR-210 and apoptosis as well as cell survival was intensively investigated. Its antiapoptotic and cytoprotective effects have been demonstrated in many studies involving not only cancer cells $[27,60,61]$ but also normal cells such as human pulmonary artery smooth muscle cells (HPASMC) [32], cardiomyocytes [24,33], bone marrowderived mesenchymal stem cells (MSCs) [31], as well as neural progenitor cells [36].

Many functional targets of miR-210 associated with apoptosis have been identified, as shown in Table 1. By downregulating the expression of caspase-8-associated protein-2 (Casp8ap2), miR-210 promoted the survival of MSCs that underwent ischemic preconditioning [31]. Through repressing the expression of regulator of differentiation 1 (ROD1), which is also named polypyrimidine tract binding protein 3 (PTBP3), miR-210 reduced the apoptosis of hypoxic cells and increased the survival of hypoxic cells [61]. E2F3, a member of the E2F family of transcriptional factors and a well-known cell cycle regulator, was identified as a direct target of miR-210 in hypoxic HPASMC, its downregulation was shown to be responsible in part for the antiapoptotic effect of miR-210 [32]. Knock down of miR-210 in hypoxic HPASMC, which resulted in concomitant upregulation of E2F3, induced apoptosis without significant change of cell proliferation, indicating the proapoptotic effect of E2F3 as well as the antiapoptotic effect of miR-210 in HPASMC under hypoxia stress [32]. The cytoprotective effect of miR-210 against radiotherapy was also investigated. Overexpression of miR-210 in A549 cell line (non-small cell lung carcinoma-derived cell line) under normoxia can protect cancer cells from radiation [57], while downregulation of miR-210 in hypoxic human hepatoma cells led to increased radiosensitivity, both in vitro and in vivo [27,62]. As elucidated by Grosso et al., A549 cells stably expressing miR-210 in normoxia exhibited similar radioresistance to A549 cells expressing miR-control in hypoxia, and hypoxia can further increase this resistance. Although the underlying mechanisms responsible for this radioresistance were not fully investigated, the authors gave us a clue that miR-210 expressing cells showed rapid repair of DNA double-strand breaks (DSBs), which might contribute to radioresistance [57]. In addition, synthetic miRNA-Mowers targeting miR-210 in bladder cancer cells can inhibit growth and migration and induce apoptosis [60].

\section{miR-210 regulates angiogenesis, promotes invasion and metastasis}

Inducing angiogenesis is another hallmark of cancer, which not only provides nutrients and oxygen, evacuates metabolic wastes and carbon dioxide to sustain cancer cells, but also facilitates metastasis [59]. Many miRNAs have been involved in tumor angiogenesis [44,63], including miR-21, miR-106a, miR-126, miR-155, miR-182, miR-210 and miR-424.

miR-210 overexpression in normoxic endothelial cells stimulated the formation of capillary-like structures and vascular endothelial growth factor-driven cell migration, while blockade had the opposite effect [41]. Ephrin-A3 (EFNA3) was identified as the direct target, whose downmodulation was necessary for miR-210 mediated stimulation of both tubulogenesis and chemotaxis [41]. Notably, hypoxia can increase the expression of EFNA3 mRNA, so the down-modulation of EFNA3 may attribute to translation inhibition [41]. Another study confirmed EFNA3 as a direct target of miR-210 through luciferase assay, however, upregulation of EFNA3 was shown in ischemia brain, which seemed to be contradictory with the hypothesis that hypoxia induced miR-210 expression would result in downregulation of EFNA3 [64]. Apparently, the unpredictable effects of miR-210 on the expression of EFNA3 need further investigation.

In hypoxic hepatocellular carcinoma (HCC), vacuole membrane protein 1 (VMP1) was identified as the direct and functional downstream target of miR-210, which mediates hypoxia-induced HCC cell migration and invasion [42]. Overexpression of miR-210 in non-invading breast cancer cell line MCF-7 cells led to cell invasion while repression of miR-210 in migrating and invading breast cell line MDA-MB-231 cells resulted in decreased cell migration and invasion [49]. Meanwhile, miR-210 contained in exosomes released by cancer cells can be transported to endothelial cells to induce angiogenesis [50].

\section{miR-210 involves in DNA repair}

Genome integrity is of vital importance for normal cells since mutations of crucial genes result in multiple diseases including cancer. Various stresses, including mutagens, ROS, ultraviolet light, radiation as well as chemotherapeutic agents can induce DNA damage, of which 
DNA double-strand break (DSB) has the most severe effect [65].

Cancer is characterized by genomic instability [59], which may result from hypoxic tumor microenvironment by affecting DNA repair capacity of cancer cells [5]. RAD52, a protein important for DNA DSB repair and homologous recombination, has been identified as a functional target of miR-210 [66]. In addition to downregulating DNA repair genes, such as RAD52, to increase genomic instability which confers aggressiveness to cancer cells, miR-210 appears to be capable of facilitating DNA DSB repair after radiation exposure, which makes cancer cells more intractable, as demonstrated by Grosso et al. [57]. NSCLC cell lines expressing miR-210 in normoxia are more resistant to radiation due to more effective DNA repair, of which the underlying mechanism remains to be elucidated.

\section{miR-210 induces immunosuppression}

During the initiation and development of cancer, cancer cells have acquired multiple mechanisms to evade immunological surveillance. Emerging evidence has shown that certain miRNAs regulate expression of genes that are critically involved in both innate and adaptive immune responses [67]. A recent study investigated the role of miR-210, up-expressed in the hypoxic zones of human tumor tissues, in inducing immunosuppression in hypoxic cancer cells [68]. They examined the susceptibility of IGR-Heu (human NSCLC cell line) and NA-8 (human melanoma cell line) cells in which miR-210 expression had been abrogated by anti-miR-210 to cytotoxic $\mathrm{T}$ cells (CTC)-mediated lysis under hypoxia, demonstrated that these cancer cells were more susceptible to CTC-mediated lysis, implying the immunosuppressive effects of miR-210 in hypoxic cancer cells. Functional analysis has identified the potential targets of miR-210, including PTPN1, HOXA1 and TP53I11 that confer immunosuppression to hypoxic cells [68].

\section{miR-210 functions as a tumor suppressor}

Controversial to the above cited multiple studies showing that miR-210 acts as an oncogene, many studies suggest that miR-210 can also act as a tumor suppressor, inhibiting tumor initiation. Table 2 summarizes the identified targets of miR-210, implying its potential role as tumor suppressor.

\section{miR-210 induces cell cycle arrest, inhibits cell proliferation, promotes apoptosis}

In the study conducted by Giannakakis et al. [18], they found that miR-210 was deleted in 50\% of ovarian cancer cell lines and $64 \%$ of ovarian cancer samples tested, implying miR-210 as a potential tumor suppressor gene. Subsequent functional analysis identified several targets

Table 2 Targets of miR-210 functioning as tumor suppressor gene

\begin{tabular}{|c|c|c|c|}
\hline Symbol & Description & Related function & Involved cell type \\
\hline \multirow[t]{5}{*}{ E2F3 $[18,21]$} & E2F transcription factor 3 & Regulate apoptosis and cell proliferation & HeLa \\
\hline & & & $\mathrm{ACHN}$ \\
\hline & & & $786-\mathrm{O}$ \\
\hline & & & Caki2 \\
\hline & & & HEK293 \\
\hline \multirow[t]{3}{*}{ FGFRL1 $[19,26]$} & fibroblast growth factor receptor-like 1 & Regulate cell proliferation & MCF10A \\
\hline & & & KYSE-170 \\
\hline & & & KYSE-590 \\
\hline PTPN2 [30] & protein tyrosine phosphatase, non-receptor type 2 & Regulate cell proliferation & ASC \\
\hline \multirow[t]{2}{*}{ PIK1 [29] } & 1-phosphatidylinositol 4-kinase & Regulate mitosis & CNE \\
\hline & & & HeLa \\
\hline \multirow[t]{2}{*}{ Cdc25B [29] } & cell division cycle $25 \mathrm{~B}$ & Regulate mitosis & CNE \\
\hline & & & HeLa \\
\hline \multirow[t]{2}{*}{ Bub1B [29] } & BUB1 mitotic checkpoint serine/threonine kinase B & Regulate mitosis & CNE \\
\hline & & & HeLa \\
\hline \multirow[t]{2}{*}{ CCNF [29] } & cyclin F & Regulate mitosis & CNE \\
\hline & & & HeLa \\
\hline \multirow[t]{2}{*}{ Fam83D [29] } & family with sequence similarity 83 , member $D$ & Regulate mitosis & CNE \\
\hline & & & HeLa \\
\hline $\mathrm{BCl}-2[34]$ & B-cell CLL/lymphoma 2 & Apoptosis & Neuro-2a \\
\hline
\end{tabular}


of miR-210, including E2F3. Contradictory to our foregoing evidence of proapoptotic effect of E2F3 in hypoxia HPASMC, E2F3 was considered as a promoter of cell proliferaion here. Overexpression of miR-210 down-regulated E2F3 expression at the translational level, suggesting that down-regulation of miR-210 expression (such as demonstrated in ovarian cancer due to gene copy aberrations) in hypoxia may increase the expression of E2F3 that promotes cell proliferation and involves in tumorigenesis [18]. However, considering that E2F3 comprises two functionally different forms, E2F3a and E2F3b, with the same 3' UTR, both E2F3a and E2F3b are targets of miR-210 [18], this interpretation warrants more experiments.

Tsuchiya et al. [26] also demonstrated the anti-proliferative role of miR-210 in cancer. They reported the downexpression of miR-210 in human esophageal squamous cell carcinoma (ESCC) and derived cell lines, and elucidated that overexpression of miR-210 in KYSE-170 (ESCC) cell line not only induces cell cycle arrest in both G0/G1 and G2/M phases, but also causes cell apoptosis and necrosis. Functional analysis identified fibroblast growth factor receptor-like 1 (FGFRL1) as the direct target.

Additional evidence has implicated miR-210 in mitotic regulation. In CNE cells treated with hypoxia mimetic agent, over-expression of exogenous miR-210 significantly decreased cell proliferation, and vice versa [29]. Molecular mechanism analysis revealed that a group of mitosisrelated genes, including Plk1, Cdc25B, Cyclin F, Bulb1B and Fam83D, are the direct targets of miR-210, suggesting its inhibitory role on tumor formation.

In addition to inhibiting apoptosis as shown previously, miR-210 can mediate hypoxia-induced apoptosis at least in neuroblastoma cells as demonstrated by Chio et al. [34]. They treated neuro-2a (neuroblastoma cell line) cells with oxygen/glucose deprivation (OGD), elucidated the important role of miR-210 in OGD-induced cell apoptosis, and identified Bcl-2 as the functional target. Overexpression of miR-210 decreased the mRNA and protein levels of Bcl-2, an anti-apoptotic gene, resulting in increased apoptosis.

\section{miR-210 and mitochondrial metabolism}

Under hypoxic conditions, cell metabolism shifts from mitochondrial oxidative phosphorylation to glycolysis (the Pasteur effect). HIF-1 plays a critical role in this effect, by up-regulating the expression of most glycolytic enzymes as well as pyruvate dehydrogenase kinase, while down-regulating mitochondrial respiration [69]. As tumors largely rely on glycolysis even under normal oxygen supply (Warburg effect) $[59,70]$ which is significantly different from normal cells, the underling molecular mechanisms deserve further investigation.
The regulation of mitochondrial metabolism during hypoxia by miR-210 was first reported by Chan et al. [52]. They utilized pulmonary arterial endothelial cells as a representative hypoxic cell type, demonstrated that miR-210 directly targets iron-sulfur cluster assembly proteins (ISCU1/2) and decreases the activity of prototypical iron-sulfur proteins controlling mitochondrial metabolism, including ComplexIand acontiase, resulting in decreased oxidative phosphorylation. Subsequent studies investigating the role of miR-210 in modulating mitochondrial function have revealed more targets of miR-210 [53-57]. Besides ISCU [54], which was further confirmed, GPD1L [20], COX10 [53], SDHD and NDUFA4 [55] were also identified as direct targets involved in mitochondrial function regulation. In the study by Puissegur et al. [55], A549 cells overexpressing miR-210 exhibited an aberrant mitochondrial phenotype, mRNA expression profiling analysis linked miR-210 to mitochondrial dysfunction. Interestingly, miR-210 acts not only as a downstream mediator of HIF- $1 \alpha$, it can also promote HIF- $1 \alpha$ stability by suppressing GPD1L, producing a positive feedback between HIF- $1 \alpha$ and miR-210 [20]. As miR-210 is highly stable, when hypoxic cells undergo reoxygenation, HIF- $1 \alpha$ is degraded immediately, but miR-210 remains stable to sustain glycolytic phenotype and inhibit mitochondrial metabolism under normoxia. Such advantage may be utilized by cancer cells, contributing to Warburg effect [57]. Taken together, the above evidence suggests an indisputable role of miR-210 in modulating mitochondrial metabolism, and facilitating adaptation of cancer cells to hypoxic condition.

\section{miR-210 as diagnostic and prognostic biomarker in cancer}

Early diagnosis and prognosis evaluation of cancer are of vital importance to improve treatment outcome. It is well acknowledged that cancer cells or tissues harbor aberrant miRNA expression profiles compared to normal cells or tissues, and specific miRNA signature can not only be used for diagnosis but also to classify cancer patients into subgroups with different prognosis guiding individualized treatment [71-77]. Many studies have investigated the role of miR-210 in cancer diagnosis and prognosis, however, presenting apparently conflicting results.

Most evidence showed that miR-210 was up-regulated in many solid tumors, including breast cancer [16,78-80], head and neck cancer [17,76], pancreatic cancer [81-83], lung cancer [55,84-87], renal cancer [23,88,89], lymphoma [90], osteosarcoma [91], esophageal cancer [92] as well as ovarian cancer [93]. There are also some inconsistent evidence that miR-210 was deleted in some cases of ovarian cancer [18], and was down-regulated in some cases of esophageal cancer [26], exhibiting the complexity and heterogeneity of cancer. 
Table 3 Studies investigating diagnostic value of miR-210

\begin{tabular}{|c|c|c|c|c|c|c|}
\hline First author & Publication year & Types of cancer & Types of sample & Negative controls & Sensitivity & Specificity \\
\hline Wang [81] & 2009 & Pancreatic cancer & plasma & Healthy controls & $53 \%$ & $78 \%$ \\
\hline Xing [86] & 2010 & Squamous cell LC & sputum & Healthy controls & $58 \%$ & $79 \%$ \\
\hline Shen [94] & 2011 & Lung cancer & plasma & Benign SPNs & $56 \%$ & $73 \%$ \\
\hline Tan [95] & 2011 & Squamous cell LC & tissue & Normal lung tissue & Not provided & Not provided \\
\hline Ren [96] & 2012 & Pancreatic cancer & stool & Healthy controls & $85 \%$ & $67 \%$ \\
\hline Li [97] & 2013 & $\mathrm{NSCLC}$ & sputum & Healthy controls & Not provided & Not provided \\
\hline Li [98] & 2013 & NSCLC & serum & Healthy controls & $79 \%$ & $74 \%$ \\
\hline Zhao [99] & 2013 & Renal cancer & serum & Healthy controls & $81 \%$ & $79 \%$ \\
\hline Iwamoto [100] & 2014 & Renal cancer & serum & Healthy controls & $65 \%$ & $83 \%$ \\
\hline
\end{tabular}

Abbreviations: LC lung cancer, NSCLC non-small cell lung cancer, SPN solitary pulmonary nodule.

Table 3 enumerates the studies [81,86,94-100] investigating the diagnostic value of miR-210, either alone or in combination with other miRNAs, providing the sensitivity and specificity of miR-210 when it was used alone to discriminate cancer from non-cancer. Because of the inherent stability of miRNAs [101], and the high sensitivity as well as specificity of quantitative RT-PCR [102], samples used for diagnosis include not only tumor tissue but also serum, plasma, sputum and stool that are more available in clinic, showing the promise of miRNAs in clinical application [103]. Notably, the diagnostic power increased when using multiple miRNAs instead of only one miRNA [81,86,94-97]. For example, in the study conducted by wang et al. [81], they profiled four pancreatic cancer related miRNAs (miR-21, miR-210, miR-155, miR-196a) as blood-based biomarker for diagnosis. The sensitivity and specificity were $42 \%$ to $53 \%$ and $73 \%$ to $89 \%$ respectively, when using only one miRNA for diagnosis, but with the panel of four miRNAs, the sensitivity and specificity increased to $64 \%$ and $89 \%$ respectively. Other similar studies also showed us similar results [86,94-97].

Table 4 lists the studies [16,17,23,78-80,82,87,90,91,104-107] investigating the prognostic value of miR-210. While most studies documented that high miR-210 expression level in tumor tissue or blood was correlated with poor diseasefree and/or overall survival and was a negative prognostic factor, at least three articles investigating soft-tissue sarcoma [104], renal cancer [23] and NSCLC [87] respectively, indicated that miR-210 was a positive prognostic factor. Obviously, the prognostic value of miR-210 expression level in specific cancer type with specific stage varies,

Table 4 Studies investigating prognostic value of miR-210

\begin{tabular}{lllll}
\hline First author & Publication year & Types of cancer & Types of sample & RR or HR (high VS low expression level) \\
\hline Camps [16] & 2008 & Breast cancer & tissue & $4.07(\mathrm{PFS}), 11.38(\mathrm{OS})$ \\
Lawrie [90] & 2008 & Diffuse large B-cell lymphoma & serum & No significance \\
Gee [17] & 2010 & Head and neck cancer & tissue & Not provided \\
Greither [82] & 2010 & Pancreatic cancer & tissue & 2.48 \\
Buffa [107] & 2011 & Breast cancer (ER ${ }^{-}$) & tissue & Not provided \\
Radiojicic [78] & 2011 & Triple-negative breast cancer & tissue & No significance \\
Rothe [80] & 2011 & Breast cancer & tissue & 4.43(RFS) \\
Greither [104] & 2012 & Soft-tissue sarcoma & tissue & $3.19(\mathrm{PFS)}$ \\
Toyama [79] & 2012 & Breast cancer & tissue & 4.39 \\
Volinia [105] & 2012 & Breast cancer & tissue & $1.54(\mathrm{OS})$ \\
Cai [91] & 2013 & Pediatric osteosarcoma & tissue & 2.6(PFS), 3.3(OS) \\
Eilertsen [87] & 2013 & Non-small cell lung cancer & tissue & $1.9(\mathrm{DSS})^{* *}$ \\
McCormick [23] & 2013 & Renal cancer & tissue & Not provided \\
Qiu [106] & 2013 & Glioblastoma & tissue & $0.75^{* *}$
\end{tabular}

intermediate VS high expression level.

\#stromal cells in tumor tissues.

***ow VS high expression level.

Abbreviations: PFS progression-free survival, OS overall survival, RFS relapse-free survival, DSS disease-specific survival, $E R^{-}$estrogen receptor negative. 
and needs more exploration. The interesting study by Buffa et al. presented us an excellent example for exploring miRNAs as prognostic factors for cancer. They conducted comprehensive miRNA and mRNA expression profiling in a large cohort of 207 early-invasive breast cancers. To identify miRNAs with independent prognostic value, they performed penalized Cox regression for distant relapse-free survival (DRFS), including all miRNAs, clinical covariates and gene signatures. At last, they detected four microRNAs to be independently associated with DRFS in estrogen receptor (ER)-positive and six in ERnegative (including miR-210) cases. To further confirm the value of these prognostic miRNAs, they also carried out correlation analysis of these miRNAs with clinicopathologic factors, indicating that miR-210 expression was associated with proliferation, ER positivity, grade, and nodal invasion. In addition, they performed prognostic analysis of pri-miRNAs and predicted target transcripts of prognostic miRNAs, as well as miRNA-processing genes, revealing that identified miRNAs were virtually independent prognostic factors. They also demonstrated that combination of miRNA and target expression could identify patients with the poorest prognosis, showing us the prospect of integrating miRNA and mRNA information for prognosis analysis.

\section{Conclusions and future directions}

As the master HRM, regulated mainly by HIF-1, miR-210 plays an essential role in hypoxic response. In addition to regulating mitochondrial metabolism, miR-210 is involved in regulating cell cycle, cell survival, differentiation, DNA repair as well as immune response.

Since hypoxia can influence both cell death and survival [108], it is not surprising that miR-210 can act both as an oncogene and a tumor suppressor, depending on cellular context, the extent and duration of hypoxia. A reasonable explanation is that since miRNAs can target hundreds of mRNAs with differential biological functions, the ultimate effect of miR-210 depends on the target mRNAs that are available in certain cells. In addition to multiple targets discussed in this review, many other genes have been identified as miR-210 targets, and more and more potential target genes are emerging [12]. An alternative possibility may be that miR-210 acts as a tumor suppressor at the beginning of tumorigenesis when hypoxia is not significant. However, with the progression of tumor, hypoxia becomes significant, tumor cells evolve, become resistant to hypoxia and adapt well to highly expressed miR-210, then miR-210 switches to an oncogene [19,29]. Due to the paradoxical functions of miR-210, more investigations are warranted before considering it as an effective therapeutic target in cancer. Future researches should elucidate the specific context that is responsible for specific functions of miR-210. In addition, how to integrate multiple functionally different but related targets of one peculiar miRNA such as miR-210, so as to precisely predict its functions remains a great challenge.

Besides functions of miR-210, we also reviewed the diagnostic and prognostic value of it. As described above, up-regulated miR-210 is not only be detected in cancer tissues, but also in body fluids. It is feasible to discriminate cancer from non-cancer with a specific group of miRNAs including miR-210. However, when it comes to prognosis, it is far too early to use miR-210 alone as a prognostic factor without dispute, and more investigations are needed to elucidate the underlying mechanism of such discrepancy. In future, global analysis of large cohorts of patients with not only miRNAs expression profile but also mRNAs expression profile, even integrated with other genetic information such as DNA copy number variance, single nucleotide polymorphisms, will provide us more insights about significant prognostic factors as well as novel therapeutic targets.

\section{Competing interests}

The authors declare that they have no competing interests.

\section{Authors' contributions}

QQ and LBS conceived the study. QQ and WFR searched the literature and drafted the manuscript. LBS edited the manuscript. All the authors have read and approved the final manuscript.

\section{Acknowledgements}

This study was supported by National Natural Science Foundation of China (Grant no. 81272501). We acknowledge Dr. David L, Roerig for critical reading of the manuscript.

\section{Author details}

${ }^{1}$ Department of Radiation Oncology, Shandong Cancer Hospital, Shandong University, Jiyan Road 440, Jinan 250117, P.R. China. ${ }^{2}$ Department of Radiation Oncology, Shandong Cancer Hospital, Shandong Academy of Medical Sciences, Jinan 250117, P.R. China. Institute of Basic Medicine, Shandong Academy of Medical Sciences, Jingshi Road 18877, Jinan 250062, P.R. China.

Received: 11 May 2014 Accepted: 1 June 2014

Published: 9 June 2014

\section{References}

1. Bartel DP: MicroRNAs: target recognition and regulatory functions. Cell 2009, 136(2):215-233.

2. Krol J, Loedige I, Filipowicz W: The widespread regulation of microRNA biogenesis, function and decay. Nat Rev Genet 2010, 11(9):597-610.

3. Almeida MI, Reis RM, Calin GA: MicroRNA history: discovery, recent applications, and next frontiers. Mutat Res 2011, 717(1-2):1-8.

4. Vaupel $P$, Mayer A: Hypoxia in cancer: significance and impact on clinical outcome. Cancer Metastasis Rev 2007, 26(2):225-239.

5. Ruan K, Song G, Ouyang G: Role of hypoxia in the hallmarks of human cancer. J Cell Biochem 2009, 107(6):1053-1062.

6. Begg AC, Stewart FA, Vens C: Strategies to improve radiotherapy with targeted drugs. Nat Rev Cancer 2011, 11(4):239-253.

7. Kulshreshtha R, Ferracin M, Wojcik SE, Garzon R, Alder H, Agosto-Perez FJ, Davuluri R, Liu CG, Croce CM, Negrini M, Calin GA, Ivan M: A microRNA signature of hypoxia. Mol Cell Biol 2007, 27(5):1859-1867.

8. Ivan M, Harris AL, Martelli F, Kulshreshtha R: Hypoxia response and microRNAs: no longer two separate worlds. J Cell Mol Med 2008, 12(5A):1426-1431. 
9. Crosby ME, Devlin CM, Glazer PM, Calin GA, Ivan M: Emerging roles of microRNAs in the molecular responses to hypoxia. Curr Pharm Des 2009, 15(33):3861-3866.

10. McCormick R, Buffa FM, Ragoussis J, Harris AL: The role of hypoxia regulated microRNAs in cancer. Curr Top Microbiol Immunol 2010, 345:47-70.

11. Nallamshetty S, Chan SY, Loscalzo J: Hypoxia: a master regulator of microRNA biogenesis and activity. Free Radic Biol Med 2013, 64:20-30.

12. Gee HE, Ivan C, Calin GA, Ivan M: HypoxamiRs and Cancer: From Biology to Targeted Therapy. Antioxid Redox Signal 2013.

13. Chan SY, Loscalzo J: MicroRNA-210: a unique and pleiotropic hypoxamir. Cell Cycle 2010, 9(6):1072-1083.

14. Devlin C, Greco S, Martelli F, Ivan M: miR-210: More than a silent player in hypoxia. IUBMB life 2011, 63(2):94-100.

15. Ivan M, Huang X: miR-210: Fine-Tuning the Hypoxic Response. Adv Exp Med Biol 2014, 772:205-227.

16. Camps C, Buffa FM, Colella S, Moore J, Sotiriou C, Sheldon H, Harris AL, Gleadle JM, Ragoussis J: hsa-miR-210 Is induced by hypoxia and is an independent prognostic factor in breast cancer. Clin Cancer Res 2008, 14(5):1340-1348.

17. Gee HE, Camps C, Buffa FM, Patiar S, Winter SC, Betts G, Homer J, Corbridge R, Cox G, West CM, Ragoussis J, Harris AL: hsa-mir-210 is a marker of tumor hypoxia and a prognostic factor in head and neck cancer. Cancer 2010, 116(9):2148-2158.

18. Giannakakis A, Sandaltzopoulos R, Greshock J, Liang S, Huang J, Hasegawa K, Li C, O'Brien-Jenkins A, Katsaros D, Weber BL, Simon C, Coukos G, Zhang $\mathrm{L}$ : miR-210 links hypoxia with cell cycle regulation and is deleted in human epithelial ovarian cancer. Cancer Biol Ther 2008, 7(2):255-264.

19. Huang X, Ding L, Bennewith KL, Tong RT, Welford SM, Ang KK, Story M, Le QT, Giaccia AJ: Hypoxia-inducible mir-210 regulates normoxic gene expression involved in tumor initiation. Mol Cell 2009, 35(6):856-867.

20. Kelly TJ, Souza AL, Clish CB, Puigserver P: A hypoxia-induced positive feedback loop promotes hypoxia-inducible factor 1alpha stability through miR-210 suppression of glycerol-3-phosphate dehydrogenase 1-like. Mol Cell Biol 2011, 31(13):2696-2706.

21. Nakada C, Tsukamoto Y, Matsuura K, Nguyen TL, Hijiya N, Uchida T, Sato F, Mimata H, Seto M, Moriyama M: Overexpression of miR-210, a downstream target of HIF1alpha, causes centrosome amplification in renal carcinoma cells. J Pathol 2011, 224(2):280-288.

22. Zhang Z, Sun H, Dai H, Walsh RM, Imakura M, Schelter J, Burchard J, Dai X, Chang AN, Diaz RL, Marszalek JR, Bartz SR, Carleton M, Cleary MA, Linsley PS, Grandori C: MicroRNA miR-210 modulates cellular response to hypoxia through the MYC antagonist MNT. Cell Cycle 2009, 8(17):2756-2768.

23. McCormick RI, Blick C, Ragoussis J, Schoedel J, Mole DR, Young AC, Selby PJ, Banks RE, Harris AL: miR-210 is a target of hypoxia-inducible factors 1 and 2 in renal cancer, regulates ISCU and correlates with good prognosis. Br J Cancer 2013, 108(5):1133-1142.

24. Mutharasan RK, Nagpal $V$, Ichikawa $Y$, Ardehali H: microRNA-210 is upregulated in hypoxic cardiomyocytes through Akt- and p53-dependent pathways and exerts cytoprotective effects. Am J Physiol Heart Circ Physio 2011, 301(4):H1519-1530.

25. Takikawa T, Masamune A, Hamada S, Nakano E, Yoshida N, Shimosegawa T: miR-210 regulates the interaction between pancreatic cancer cells and stellate cells. Biochem Biophys Res Commun 2013, 437(3):433-439.

26. Tsuchiya S, Fujiwara T, Sato F, Shimada Y, Tanaka E, Sakai Y, Shimizu K, Tsujimoto G: MicroRNA-210 regulates cancer cell proliferation through targeting fibroblast growth factor receptor-like 1 (FGFRL1). J Biol Chem 2011, 286(1):420-428.

27. Yang W, Sun T, Cao J, Liu F, Tian Y, Zhu W: Downregulation of miR-210 expression inhibits proliferation, induces apoptosis and enhances radiosensitivity in hypoxic human hepatoma cells in vitro. Exp Cell Res 2012, 318(8):944-954.

28. Biswas S, Roy S, Banerjee J, Hussain SR, Khanna S, Meenakshisundaram G, Kuppusamy P, Friedman A, Sen CK: Hypoxia inducible microRNA 210 attenuates keratinocyte proliferation and impairs closure in a murine model of ischemic wounds. Proc Natl Acad Sci U S A 2010, 107(15):6976-6981.

29. He J, Wu J, Xu N, Xie W, Li M, Li J, Jiang Y, Yang BB, Zhang Y: MiR-210 disturbs mitotic progression through regulating a group of mitosis-related genes. Nucleic Acids Res 2013, 41(1):498-508.
30. Kim JH, Park SG, Song SY, Kim JK, Sung JH: Reactive oxygen speciesresponsive miR-210 regulates proliferation and migration of adipose-derived stem cells via PTPN2. Cell Death Dis 2013, 4:e588.

31. Kim HW, Haider HK, Jiang S, Ashraf M: Ischemic preconditioning augments survival of stem cells via miR-210 expression by targeting caspase-8-associated protein 2. J Biol Chem 2009, 284(48):33161-33168.

32. Gou D, Ramchandran R, Peng X, Yao L, Kang K, Sarkar J, Wang Z, Zhou G, Raj JU: miR-210 has an antiapoptotic effect in pulmonary artery smooth muscle cells during hypoxia. Am J Physiol Lung Cell Mol Physiol 2012, 303(8):L682-691.

33. Hu S, Huang M, Li Z, Jia F, Ghosh Z, Lijkwan MA, Fasanaro P, Sun N, Wang X, Martelli F, Robbins RC, Wu JC: MicroRNA-210 as a novel therapy for treatment of ischemic heart disease. Circulation 2010, 122(11 Suppl):S124-131.

34. Chio CC, Lin JW, Cheng HA, Chiu WT, Wang YH, Wang JJ, Hsing CH, Chen RM: MicroRNA-210 targets antiapoptotic Bcl-2 expression and mediates hypoxia-induced apoptosis of neuroblastoma cells. Arch Toxicol 2013, 87(3):459-468

35. Qiu J, Zhou XY, Zhou XG, Cheng R, Liu HY, Li Y: Neuroprotective effects of microRNA-210 against oxygen-glucose deprivation through inhibition of apoptosis in PC12 cells. Mol Med Rep 2013, 7(6):1955-1959.

36. Wang $F$, Xiong L, Huang $X$, Zhao T, Wu LY, Liu ZH, Ding X, Liu S, Wu Y, Zhao Y, Wu K, Zhu LL, Fan M: miR-210 suppresses BNIP3 to protect against the apoptosis of neural progenitor cells. Stem Cell Res 2013, 11(1):657-667.

37. Mizuno Y, Tokuzawa Y, Ninomiya Y, Yagi K, Yatsuka-Kanesaki Y, Suda T, Fukuda T, Katagiri T, Kondoh Y, Amemiya T, Tashiro H, Okazaki Y: miR-210 promotes osteoblastic differentiation through inhibition of AcvR1b. FEBS Lett 2009, 583(13):2263-2268.

38. Cicchillitti L, Di Stefano V, Isaia E, Crimaldi L, Fasanaro P, Ambrosino V, Antonini A, Capogrossi MC, Gaetano C, Piaggio G, Martelli F: Hypoxiainducible factor 1-alpha induces miR-210 in normoxic differentiating myoblasts. J Biol Chem 2012, 287(53):44761-44771.

39. Gong Y, Xu F, Zhang L, Qian Y, Chen J, Huang H, Yu Y: MicroRNA expression signature for Satb2-induced osteogenic differentiation in bone marrow stromal cells. Mol Cell Biochem 2014, 387:227-239.

40. Sarakul O, Vattanaviboon P, Tanaka Y, Fucharoen S, Abe Y, Svasti S, Umemura T: Enhanced erythroid cell differentiation in hypoxic condition is in part contributed by miR-210. Blood Cells Mol Dis 2013, 51(2):98-103.

41. Fasanaro P, D'Alessandra Y, Di Stefano V, Melchionna R, Romani S, Pompilio G, Capogrossi MC, Martelli F: MicroRNA-210 modulates endothelial cell response to hypoxia and inhibits the receptor tyrosine kinase ligand Ephrin-A3. J Biol Chem 2008, 283(23):15878-15883.

42. Ying Q, Liang L, Guo W, Zha R, Tian Q, Huang S, Yao J, Ding J, Bao M, Ge C, Yao M, Li J, He X: Hypoxia-inducible microRNA-210 augments the metastatic potential of tumor cells by targeting vacuole membrane protein 1 in hepatocellular carcinoma. Hepatology 2011, 54(6):2064-2075.

43. Alaiti MA, Ishikawa M, Masuda H, Simon DI, Jain MK, Asahara T, Costa MA: Up-regulation of miR-210 by vascular endothelial growth factor in ex vivo expanded CD34+ cells enhances cell-mediated angiogenesis. J Cell Mol Med 2012, 16(10):2413-2421.

44. Donnem T, Fenton CG, Lonvik K, Berg T, Eklo K, Andersen S, Stenvold H, Al-Shibli K, Al-Saad S, Bremnes RM, Busund LT: MicroRNA signatures in tumor tissue related to angiogenesis in non-small cell lung cancer. PLoS One 2012, 7(1):e29671.

45. Liu F, Lou YL, Wu J, Ruan QF, Xie A, Guo F, Cui SP, Deng ZF, Wang Y: Upregulation of microRNA-210 regulates renal angiogenesis mediated by activation of VEGF signaling pathway under ischemia/perfusion injury in vivo and in vitro. Kidney Blood Press Res 2012, 35(3):182-191.

46. Lou YL, Guo F, Liu F, Gao FL, Zhang PQ, Niu X, Guo SC, Yin JH, Wang Y, Deng ZF: miR-210 activates notch signaling pathway in angiogenesis induced by cerebral ischemia. Mol Cell Biochem 2012, 370(1-2):45-51.

47. Shoji T, Nakasa T, Yamasaki K, Kodama A, Miyaki S, Niimoto T, Okuhara A, Kamei N, Adachi N, Ochi M: The effect of intra-articular injection of microRNA-210 on ligament healing in a rat model. Am J Sports Med 2012, 40(11):2470-2478.

48. Yamasaki K, Nakasa T, Miyaki S, Yamasaki T, Yasunaga Y, Ochi M: Angiogenic microRNA-210 is present in cells surrounding osteonecrosis. J Orthop Res 2012, 30(8):1263-1270.

49. Kosaka N, Iguchi H, Hagiwara K, Yoshioka Y, Takeshita F, Ochiya T: Neutral sphingomyelinase 2 (nSMase2)-dependent exosomal transfer of 
angiogenic microRNAs regulate cancer cell metastasis. J Biol Chem 2013, 288(15):10849-10859.

50. Tadokoro H, Umezu T, Ohyashiki K, Hirano T, Ohyashiki JH: Exosomes derived from hypoxic leukemia cells enhance tube formation in endothelial cells. J Biol Chem 2013, 288(48):34343-34351.

51. Zeng L, He X, Wang Y, Tang Y, Zheng C, Cai H, Liu J, Wang Y, Fu Y, Yang GY: MicroRNA-210 overexpression induces angiogenesis and neurogenesis in the normal adult mouse brain. Gene Ther 2014, 21:37-43.

52. Chan SY, Zhang YY, Hemann C, Mahoney CE, Zweier JL, Loscalzo J: MicroRNA-210 controls mitochondrial metabolism during hypoxia by repressing the iron-sulfur cluster assembly proteins ISCU1/2. Cell Metab 2009, 10(4):273-284.

53. Chen Z, Li Y, Zhang H, Huang P, Luthra R: Hypoxia-regulated microRNA-210 modulates mitochondrial function and decreases ISCU and COX10 expression. Oncogene 2010, 29(30):4362-4368.

54. Favaro E, Ramachandran A, McCormick R, Gee H, Blancher C, Crosby M, Devlin C, Blick C, Buffa F, Li JL, Vojnovic B, Pires das Neves R, Glazer P, Iborra F, Ivan M, Ragoussis J, Harris AL: MicroRNA-210 regulates mitochondrial free radical response to hypoxia and krebs cycle in cancer cells by targeting iron sulfur cluster protein ISCU. PLoS One 2010, 5(4):e10345.

55. Puissegur MP, Mazure NM, Bertero T, Pradelli L, Grosso S, Robbe-Sermesant K, Maurin T, Lebrigand K, Cardinaud B, Hofman V, Fourre S, Magnone V, Ricci JE, Pouysségur J, Gounon P, Hofman P, Barbry P, Mari B: miR-210 is overexpressed in late stages of lung cancer and mediates mitochondrial alterations associated with modulation of HIF-1 activity. Cell Death Differ 2011, 18(3):465-478.

56. Colleoni F, Padmanabhan N, Yung HW, Watson ED, Cetin I, van Patot MC T, Burton GJ, Murray AJ: Suppression of mitochondrial electron transport chain function in the hypoxic human placenta: a role for miRNA-210 and protein synthesis inhibition. PLOS One 2013, 8(1):e55194.

57. Grosso S, Doyen J, Parks SK, Bertero T, Paye A, Cardinaud B, Gounon P, Lacas-Gervais S, Noel A, Pouyssegur J, Barbry P, Mazure NM, Mari B: MiR-210 promotes a hypoxic phenotype and increases radioresistance in human lung cancer cell lines. Cell Death Dis 2013, 4:e544.

58. Bertero T, Robbe-Sermesant K, Le Brigand K, Ponzio G, Pottier N, Rezzonico R, Mazure NM, Barbry P, Mari B: microRNAs target identification: lessons from hypoxamiRs. Antioxid Redox Signal 2013.

59. Hanahan D, Weinberg RA: Hallmarks of cancer: the next generation. Cell 2011, 144(5):646-674

60. Liu Y, Han Y, Zhang H, Nie L, Jiang Z, Fa P, Gui Y, Cai Z: Synthetic miRNA-mowers targeting miR-183-96-182 cluster or miR-210 inhibit growth and migration and induce apoptosis in bladder cancer cells. PLoS One 2012, 7(12):e52280.

61. Fasanaro P, Romani S, Voellenkle C, Maimone B, Capogrossi MC, Martelli F: ROD1 is a seedless target gene of hypoxia-induced miR-210. PLoS One 2012, 7(9):e44651.

62. Yang W, Wei J, Sun T, Liu F: Effects of knockdown of miR-210 in combination with ionizing radiation on human hepatoma xenograft in nude mice. Radiat Oncol 2013, 8:102.

63. Hua Z, Lv Q, Ye W, Wong CK, Cai G, Gu D, Ji Y, Zhao C, Wang J, Yang BB, Zhang Y: MiRNA-directed regulation of VEGF and other angiogenic factors under hypoxia. PLoS One 2006, 1:e116.

64. Pulkkinen K, Malm T, Turunen M, Koistinaho J, Yla-Herttuala S: Hypoxia induces microRNA miR-210 in vitro and in vivo ephrin-A3 and neuronal pentraxin 1 are potentially regulated by miR-210. FEBS Lett 2008, 582(16):2397-2401

65. Cann KL, Hicks GG: Regulation of the cellular DNA double-strand break response. Biochem Cell Biol 2007, 85(6):663-674.

66. Crosby ME, Kulshreshtha $R$, Ivan M, Glazer PM: MicroRNA regulation of DNA repair gene expression in hypoxic stress. Cancer Res 2009, 69(3):1221-1229.

67. Okada H, Kohanbash G, Lotze MT: MicroRNAs in immune regulationopportunities for cancer immunotherapy. Int J Biochem Cell Biol 2010, 42(8):1256-1261.

68. Noman MZ, Buart S, Romero P, Ketari S, Janji B, Mari B, Mami-Chouaib $F$, Chouaib S: Hypoxia-inducible miR-210 regulates the susceptibility of tumor cells to lysis by cytotoxic T cells. Cancer Res 2012, 72(18):4629-4641.

69. Denko NC: Hypoxia, HIF1 and glucose metabolism in the solid tumour. Nat Rev Cancer 2008, 8(9):705-713.
70. Elf SE, Chen J: Targeting glucose metabolism in patients with cancer. Cancer 2014, 120:774-780.

71. Lu J, Getz G, Miska EA, Alvarez-Saavedra E, Lamb J, Peck D, Sweet-Cordero A, Ebert BL, Mak RH, Ferrando AA, Downing JR, Jacks T, Horvitz HR, Golub TR: MicroRNA expression profiles classify human cancers. Nature 2005, 435(7043):834-838.

72. Boeri M, Verri C, Conte D, Roz L, Modena P, Facchinetti F, Calabro E, Croce CM, Pastorino U, Sozzi G: MicroRNA signatures in tissues and plasma predict development and prognosis of computed tomography detected lung cancer. Proc Natl Acad Sci U S A 2011, 108(9):3713-3718.

73. Cheng HH, Mitchell PS, Kroh EM, Dowell AE, Chery L, Siddiqui J, Nelson PS, Vessella RL, Knudsen BS, Chinnaiyan AM, Pienta KJ, Morrissey C, Tewari M: Circulating microRNA profiling identifies a subset of metastatic prostate cancer patients with evidence of cancer-associated hypoxia. PLOS One 2013, 8(7):e69239.

74. Yanaihara N, Caplen N, Bowman E, Seike M, Kumamoto K, Yi M, Stephens RM, Okamoto A, Yokota J, Tanaka T, Calin GA, Liu CG, Croce CM, Harris CC: Unique microRNA molecular profiles in lung cancer diagnosis and prognosis. Cancer Cell 2006, 9(3):189-198.

75. Fridman E, Dotan Z, Barshack I, David MB, Dov A, Tabak S, Zion O, Benjamin S, Benjamin H, Kuker H, Avivi C, Rosenblatt K, Polak-Charcon S, Ramon J, Rosenfeld N, Spector Y: Accurate molecular classification of renal tumors using microRNA expression. J Mol Diagn 2010, 12(5):687-696.

76. Scapoli L, Palmieri A, Lo Muzio L, Pezzetti F, Rubini C, Girardi A, Farinella F, Mazzotta M, Carinci F: MicroRNA expression profiling of oral carcinoma identifies new markers of tumor progression. Int J Immunopathol Pharmacol 2010, 23(4):1229-1234

77. Lages E, Guttin A, El Atifi M, Ramus C, Ipas H, Dupre I, Rolland D, Salon C, Godfraind C, DeFraipont F, Dhobb M, Pelletier L, Wion D, Gay E, Berger F, Issartel JP: MicroRNA and target protein patterns reveal physiopathological features of glioma subtypes. PLoS One 2011, 6(5):e20600.

78. Radojicic J, Zaravinos A, Vrekoussis T, Kafousi M, Spandidos DA, Stathopoulos EN: MicroRNA expression analysis in triple-negative (ER, PR and Her2/neu) breast cancer. Cell Cycle 2011, 10(3):507-517.

79. Toyama T, Kondo N, Endo Y, Sugiura H, Yoshimoto N, Iwasa M, Takahashi S, Fujii $Y$, Yamashita H: High expression of microRNA-210 is an independent factor indicating a poor prognosis in Japanese triple-negative breast cancer patients. Jpn J Clin Oncol 2012, 42(4):256-263.

80. Rothe F, Ignatiadis M, Chaboteaux C, Haibe-Kains B, Kheddoumi N, Majjaj S, Badran B, Fayyad-Kazan H, Desmedt C, Harris AL, Piccart M, Sotiriou C: Global microRNA expression profiling identifies MiR-210 associated with tumor proliferation, invasion and poor clinical outcome in breast cancer. PLoS One 2011, 6(6):e20980.

81. Wang J, Chen J, Chang P, LeBlanc A, Li D, Abbruzzesse JL, Frazier ML, Killary AM, Sen S: MicroRNAs in plasma of pancreatic ductal adenocarcinoma patients as novel blood-based biomarkers of disease. Cancer Prev Res (Phila) 2009, 2(9):807-813.

82. Greither T, Grochola LF, Udelnow A, Lautenschlager C, Wurl P, Taubert H: Elevated expression of microRNAs 155, 203, 210 and 222 in pancreatic tumors is associated with poorer survival. Int J Cancer 2010, 126(1):73-80

83. Papaconstantinou IG, Manta A, Gazouli M, Lyberopoulou A, Lykoudis PM, Polymeneas G, Voros D: Expression of microRNAs in patients with pancreatic cancer and its prognostic significance. Pancreas 2013, 42(1):67-71

84. Cho WC, Chow AS, Au JS: Restoration of tumour suppressor hsa-miR-145 inhibits cancer cell growth in lung adenocarcinoma patients with epidermal growth factor receptor mutation. Eur J Cancer 2009, 45(12):2197-2206.

85. Miko E, Czimmerer Z, Csanky E, Boros G, Buslig J, Dezso B, Scholtz B: Differentially expressed microRNAs in small cell lung cancer. Exp Lung Res 2009, 35(8):646-664

86. Xing L, Todd NW, Yu L, Fang H, Jiang F: Early detection of squamous cell lung cancer in sputum by a panel of microRNA markers. Mod Pathol 2010, 23(8):1157-1164.

87. Eilertsen M, Andersen S, Al-Saad S, Richardsen E, Stenvold H, Hald SM, Al-Shibli K, Donnem T, Busund LT, Bremnes RM: Positive prognostic impact of miR-210 in non-small cell lung cancer. Lung Cancer 2014, 83:272-278

88. Neal CS, Michael MZ, Rawlings LH, Van der Hoek MB, Gleadle JM: The VHLdependent regulation of microRNAs in renal cancer. BMC Med 2010, 8:64. 
89. Redova M, Poprach A, Besse A, lliev R, Nekvindova J, Lakomy R, Radova L, Svoboda M, Dolezel J, Vyzula R, Slaby O: MiR-210 expression in tumor tissue and in vitro effects of its silencing in renal cell carcinoma. Tumour Biol 2013, 34(1):481-491.

90. Lawrie CH, Gal S, Dunlop HM, Pushkaran B, Liggins AP, Pulford K, Banham AH, Pezzella F, Boultwood J, Wainscoat JS, Hatton CS, Harris AL: Detection of elevated levels of tumour-associated microRNAs in serum of patients with diffuse large B-cell lymphoma. Br J Haematol 2008, 141(5):672-675.

91. Cai H, Lin L, Cai H, Tang M, Wang Z: Prognostic evaluation of microRNA-210 expression in pediatric osteosarcoma. Med Oncol 2013, 30(2):499.

92. Liu SG, Qin XG, Zhao BS, Qi B, Yao WJ, Wang TY, Li HC, Wu XN: Differential expression of miRNAs in esophageal cancer tissue. Oncol Lett 2013, 5(5):1639-1642.

93. Vaksman O, Stavnes HT, Kaern J, Trope CG, Davidson B, Reich R: miRNA profiling along tumour progression in ovarian carcinoma. J Cell Mol Med 2011, 15(7):1593-1602.

94. Shen J, Liu Z, Todd NW, Zhang H, Liao J, Yu L, Guarnera MA, Li R, Cai L, Zhan M, Jiang F: Diagnosis of lung cancer in individuals with solitary pulmonary nodules by plasma microRNA biomarkers. BMC Cancer 2011, 11:374.

95. Tan X, Qin W, Zhang L, Hang J, Li B, Zhang C, Wan J, Zhou F, Shao K, Sun Y, Wu J, Zhang X, Qiu B, Li N, Shi S, Feng X, Zhao S, Wang Z, Zhao X, Chen Z, Mitchelson K, Cheng J, Guo Y, He J: A 5-microRNA signature for lung squamous cell carcinoma diagnosis and hsa-miR-31 for prognosis. Clin Cancer Res 2011, 17(21):6802-6811.

96. Ren Y, Gao J, Liu JQ, Wang XW, Gu JJ, Huang HJ, Gong YF, Li ZS: Differential signature of fecal microRNAs in patients with pancreatic cancer. Mol Med Rep 2012, 6(1):201-209.

97. Li N, Ma J, Guarnera MA, Fang H, Cai L, Jiang F: Digital PCR quantification of miRNAs in sputum for diagnosis of lung cancer. J Cancer Res Clin Oncol 2014, 140:145-150

98. Li ZH, Zhang H, Yang ZG, Wen GQ, Cui YB, Shao GG: Prognostic significance of serum microRNA-210 levels in nonsmall-cell lung cancer. $J$ Int Med Res 2013, 41(5):1437-1444.

99. Zhao A, Li G, Peoc'h M, Genin C, Gigante M: Serum miR-210 as a novel biomarker for molecular diagnosis of clear cell renal cell carcinoma. Exp Mol Pathol 2013, 94(1):115-120.

100. Iwamoto H, Kanda Y, Sejima T, Osaki M, Okada F, Takenaka A: Serum miR-210 as a potential biomarker of early clear cell renal cell carcinoma. Int J Oncol 2014, 44(1):53-58.

101. Jung M, Schaefer A, Steiner I, Kempkensteffen C, Stephan C, Erbersdobler A, Jung K: Robust microRNA stability in degraded RNA preparations from human tissue and cell samples. Clin Chem 2010, 56(6):998-1006.

102. Mitchell PS, Parkin RK, Kroh EM, Fritz BR, Wyman SK, PogosovaAgadjanyan EL, Peterson A, Noteboom J, O'Briant KC, Allen A, Lin DW, Urban N, Drescher CW, Knudsen BS, Stirewalt DL, Gentleman R, Vessella RL, Nelson PS, Martin DB, Tewari M: Circulating microRNAs as stable blood-based markers for cancer detection. Proc Natl Acad Sci U S A 2008, 105(30):10513-10518.

103. $M a R$, Jiang $T$, Kang $X$ : Circulating microRNAs in cancer: origin, function and application. J Exp Clin Cancer Res 2012, 31:38.

104. Greither T, Wurl P, Grochola L, Bond G, Bache M, Kappler M, Lautenschlager C, Holzhausen HJ, Wach S, Eckert AW, Taubert H: Expression of microRNA 210 associates with poor survival and age of tumor onset of soft-tissue sarcoma patients. Int J Cancer 2012, 130(5):1230-1235.

105. Volinia S, Galasso M, Sana ME, Wise TF, Palatini J, Huebner K, Croce CM: Breast cancer signatures for invasiveness and prognosis defined by deep sequencing of microRNA. Proc Natl Acad Sci U S A 2012, 109(8):3024-3029.

106. Qiu S, Lin S, Hu D, Feng Y, Tan Y, Peng Y: Interactions of miR-323/ miR-326/miR-329 and miR-130a/miR-155/miR-210 as prognostic indicators for clinical outcome of glioblastoma patients. J Trans/ Med 2013, 11:10.
107. Buffa FM, Camps C, Winchester L, Snell CE, Gee HE, Sheldon H, Taylor M, Harris AL, Ragoussis J: microRNA-associated progression pathways and potential therapeutic targets identified by integrated mRNA and microRNA expression profiling in breast cancer. Cancer Res 2011, 71(17):5635-5645.

108. Schmaltz C, Hardenbergh PH, Wells A, Fisher DE: Regulation of proliferation-survival decisions during tumor cell hypoxia. Mol Cell Biol 1998, 18(5):2845-2854.

doi:10.1186/1756-9966-33-50

Cite this article as: Qin et al:: Multiple functions of hypoxia-regulated miR-210 in cancer. Journal of Experimental \& Clinical Cancer Research 2014 33:50.

\section{Submit your next manuscript to BioMed Central and take full advantage of:}

- Convenient online submission

- Thorough peer review

- No space constraints or color figure charges

- Immediate publication on acceptance

- Inclusion in PubMed, CAS, Scopus and Google Scholar

- Research which is freely available for redistribution

Submit your manuscript at www.biomedcentral.com/submit
C Biomed Central 